\title{
COMPARATIVE STUDY ON CONDITIONS FOR LMA INSERTION WITH TWO DIFFERENT LOW DOSES OF SUCCINYLCHOLINE FOLLOWING THIOPENTONE INDUCTION
}

\author{
Shanmugasundaram Palanisamy1, Balasubramaniam. Solaiappan², Ravikumar Munuswamy³
}

${ }_{1}^{1}$ Associate Professor, Department of Anaesthesiology, Government Chengalpattu Medical College, Affiliated to Tamilnadu Dr. M.G.R Medical University, Chengalpattu.

${ }^{2}$ Professor, Department of Anaesthesiology, Government Chengalpattu Medical College, Affiliated to Tamilnadu Dr. M.G.R Medical University, Chengalpattu.

${ }^{3}$ Assistant Professor, Department of Anaesthesiology, Government Chengalpattu Medical College, Affiliated to Tamilnadu Dr. M.G.R

Medical University, Chengalpattu.

\section{ABSTRACT}

\section{BACKGROUND}

Propofol is the most commonly used induction agent for laryngeal mask airway insertion. Thiopentone produces less satisfactory conditions because it does not suppress the upper airway reflexes adequately. The use of rapid onset, short-acting neuromuscular blocking drug such as succinylcholine suppresses the laryngeal reflexes and aids easy insertion of laryngeal mask airway during thiopentone induction. Because of the allergic potential for propofol, the study was designed to assess the effectiveness of low doses of succinylcholine in the insertion of laryngeal mask airway during thiopentone induction.

The aim of the study is to compare the conditions for Laryngeal Mask Airway insertion with low doses of succinylcholine 0.5 $\mathrm{mg} / \mathrm{kg}$ and $1.0 \mathrm{mg} / \mathrm{kg}$ body weight following Thiopentone induction.

\section{MATERIALS AND METHODS}

The study was conducted in the Department of Anaesthesiology, Govt. Chengalpattu Medical College, Tamilnadu in fifty patients of ASA physical status I and II undergoing elective short surgical procedures lasting less than or equal to 45 minutes were included in the study. Patients belonged to the age group of 18-45 years of both sexes. All patients were premedicated with Inj. Glycopyrrolate $4 \mathrm{mcg} / \mathrm{kg}$ intramuscularly and Inj. Pentazocine $0.5 \mathrm{mg} / \mathrm{kg} 45$ minutes prior to surgery. The patients were systematically randomised into groups of 25 each, Group I received Inj. Thiopentone $5 \mathrm{mg} / \mathrm{Kg}$ and succinylcholine $0.5 \mathrm{mg} / \mathrm{Kg}$ and Group II received Inj. Thiopentone $5 \mathrm{mg} / \mathrm{Kg}$ and succinylcholine $1.0 \mathrm{mg} / \mathrm{Kg}$. Haemodynamic monitoring, fasciculations, coughing, gagging, laryngospasm, number of attempts for successful insertion, duration of apnoea, time for spontaneous resumption of respiration were noted.

Statistical Analysis- The data was analysed by statistical software SPSS 17.0 and XLSTAT 2013. Student's "t" test was used to find out the continuous data in between two groups and chi square test was used to analyse categorical data.

\section{RESULTS}

The two groups were comparable in their baseline characteristics like age, sex, weight. The degree of fasciculations were more in Group II compared to Group I, and the time for spontaneous resumption of respiration were significantly reduced in group I compared to Group II.

\section{CONCLUSION}

We have demonstrated that following thiopentone induction, administration of $0.5 \mathrm{mg} / \mathrm{kg}$ succinylcholine IV provides optimal conditions for Laryngeal mask airway insertion which is as good as administration of $1.0 \mathrm{mg} / \mathrm{kg}$ of succinylcholine with the apnoea time being significantly shorter.

\section{KEYWORDS}

LMA, Succinylcholine.

HOW TO CITE THIS ARTICLE: Palanisamy S, Solaiappan B, Munuswamy R. Comparative study on conditions for LMA insertion with two different low doses of succinylcholine following thiopentone induction. J. Evolution Med. Dent. Sci. 2017;6(22):17671771, DOI: $10.14260 / \mathrm{Jemds} / 2017 / 389$

\section{BACKGROUND}

Laryngeal mask airway is a useful scientific advancement in the management of airway filling the niche between the anatomical facemask and tracheal tubes. Various induction agents can be used for the insertion of laryngeal mask airway. Propofol is the most common agent used for the insertion of

Financial or Other, Competing Interest: None.

Submission 21-02-2017, Peer Review 05-03-2017,

Acceptance 08-03-2017, Published 16-03-2017.

Corresponding Author:

Dr. Shanmugasundaram Palanisamy,

\#No. 7, Sakthivel Nagar, Kolathur,

Chennai-99, Tamilnadu.

E-mail: shansruthi@gmail.com

DOI: $10.14260 /$ jemds $/ 2017 / 389$

\section{(c) $(\mathbf{P})$}

laryngeal mask airway. In some patients, Propofol produces allergic reactions and in some patients, sole use of propofol ${ }^{1}$ alone does not always guarantee successful insertion of laryngeal mask airway. Thiopentone can also be used, but produces less satisfactory conditions for laryngeal mask insertion. Various methods are used to suppress the airway reflexes. $^{2}$ Adverse effects like gagging, coughing, laryngospasm have been reported in thiopentone because it does not suppress the upper airway reflexes adequately. Comparisons have been made between low doses of short acting non-depolarising neuromuscular blocking ${ }^{3}$ drugs for insertion of laryngeal mask airway during thiopentone anaesthesia. The successful insertion of laryngeal mask airway requires depression of upper airway reflexes. The use of rapid onset, short-acting neuromuscular blocking drug 
such as succinylcholine in low doses ${ }^{4}$ suppress the laryngeal reflexes and aids easy insertion of laryngeal mask airway during thiopentone induction.

\section{MATERIALS AND METHODS}

This was a prospective, double blind randomised comparative study in Govt. Chengalpattu Medical College after obtaining permission from ethical committee. Written informed consent from each patient was obtained in their vernacular language and study was explained in detail to them. A pilot study was first conducted to define the population and to decide on the inclusion and exclusion criteria, and the target population of 25 subjects in each group was decided. Fifty patients of ASA physical status I and II undergoing elective short surgical procedures lasting less than or equal to 45 minutes were included in the study like fibroadenoma excision, hydrocoele excision and eversion of sac, lipoma excision, sebaceous cyst excision and gynaecomastia. Patients belonging to the age group of 18-45 years of both the sexes.

\section{Inclusion Criteria}

1. Patients of ASA physical status I and II.

2. Patients with Modified Mallampati Score I and II.

3. Elective short surgical procedures lasting less than or equal to 45 minutes.

\section{Exclusion Criteria}

1. Patients with full stomach.

2. Restricted mouth opening.

3. Patients posted for emergency surgeries.

4. Patients with oral, peri-oral pathology such as tumours, abscesses grossly enlarged tonsils.

5. Patients with fixed reduced pulmonary compliance such as pulmonary fibrosis.

6. Pregnancy.

7. Ischaemic heart disease.

8. Patient refusal.

Fifty Patients satisfying the selection criteria were randomised into two groups. Group I received Inj. Thiopentone $5 \mathrm{mg} / \mathrm{kg}$ and succinylcholine $0.5 \mathrm{mg} / \mathrm{kg}$ and Group II received Inj. Thiopentone $5 \mathrm{mg} / \mathrm{Kg}$ and succinylcholine $1.0 \mathrm{mg} / \mathrm{Kg}$. Laryngeal mask airway insertion was performed by the anaesthetist using the device with three years' experience.

\section{Study Methods}

All consented patients classified under ASA I and II were selected. They were randomly allocated using computer generated randomisation table into two groups Group I and Group II. The randomization sequence was prepared in double blinded manner.

The study drug dosage was prepared by the author. LMA insertion was done by an Assistant Professor with more than 3 years of experience in LMA insertion. The monitoring of parameters was done by a junior resident who was not involved in the study.

All patients were advised overnight fasting. All patients were premedicated with Inj. Glycopyrrolate $4 \mathrm{mcg} / \mathrm{Kg} \mathrm{mg}$ IM and Inj. Pentazocine $0.5 \mathrm{mg} / \mathrm{Kg}$ IM 45 minutes before surgery. After premedication patients were wheeled into operation theatres and monitors pulse oximeter, ECG and NIBP were attached and baseline parameters were recorded. IV line was started. After preoxygenation for 3 minutes, Group I patients received Inj. Thiopentone $5 \mathrm{mg} / \mathrm{Kg}$ over a period of thirty seconds followed by Inj. Succinylcholine $0.5 \mathrm{mg} / \mathrm{Kg}$ and Group II received Inj. Thiopentone $5 \mathrm{mg} / \mathrm{kg}$ over a period of $30 \mathrm{sec}$. followed by Inj. Succinylcholine $1.0 \mathrm{mg} / \mathrm{Kg}$. Patients were then maintained on assisted ventilation with $100 \%$ oxygen over a period of 1 minute. During that period, fasciculations were observed. At the end of 1 minute, Laryngeal mask airway was inserted by a standard technique by a person unaware of study drug used. During insertion of laryngeal mask airway, jaw relaxation, gagging, coughing, presence or absence of laryngospasm was noted.

After insertion of laryngeal mask airway, cuff was inflated with appropriate volume of air and connected to Magill's circuit and correct positioning was confirmed by observation of bilateral chest expansion and air entry after squeezing the reservoir bag. Ventilation was assisted with bag and mask until the resumption of spontaneous ventilation.

\section{Observations}

In our study, the following parameters were observed.

1. Pulse rate.

2. Blood pressure (Systolic and diastolic).

3. Fasciculations.

4. Number of attempts for successful insertion of LMA.

5. Jaw relaxation.

6. Coughing, gagging,

7. Time for spontaneous resumption of respiration.

Fasciculations were graded according to Mingus, Herlich and Eisenkraft. Grade 1- No fasciculations, Grade 2- Mild fasciculations of the eyes, face, neck or fingers without limb movement. Grade 3- Moderate fasciculations involving limbs and or trunk. Grade 4- Severe fasciculations with movement of one or more limbs. Jaw relaxation was graded according to Young, Clarke and Dundee. Grade 1- Good- adequate jaw relaxation with laryngeal mask insertion was done without difficulty. Grade 2- Incomplete- Inadequate jaw relaxation but laryngeal mask insertion is possible with difficulty. Grade 3Poor- Inadequate jaw relaxation and laryngeal mask insertion is not possible. Gagging or coughing on insertion were scored on a four-point scale, according to Nimmo and Colleagues; 1None, 2-Mild, 3-Moderate, 4-Severe. The duration of apnoea period was observed in both the study groups. Anaesthesia was maintained with oxygen and nitrous oxide and sevoflurane with spontaneous ventilation.

Heart rate, systolic and diastolic blood pressure were measured before premedication, 1 minute prior to induction, 30 seconds after induction and 1 minute after laryngeal mask airway insertion.

\section{Statistical Analysis}

The data was analysed by statistical software SPSS 17.0 and XLSTAT 2013. Student $t$ test was used to find the significance in continuous data between the two groups. Chi-square test was used to analyse categorical data.

\section{RESULTS}

The two groups were comparable to age, sex and weight. The mean age group in Group I was $28.04 \pm 7.18$ and in Group II 
was $29.64 \pm 7.15$. The mean weight in group I was $51.52 \pm 8.16$ and in Group II was $49.56 \pm 7.41$ (Table 1).

$88 \%$ of patients in Group I has mild fasciculations and $92 \%$ of patients in Group II had moderate fasciculations ( $p$ value 0.001) (Table 2). There was a significant difference between the degrees of fasciculations in these groups. Jaw relaxation was good in $92 \%$ of patients in Group I and $96 \%$ of patients in Group II ( $p$ value 0.55). There was no significant difference between these two groups in jaw relaxation (Table 2). In 22 patients in Group I and 23 patients in Group II, laryngeal mask airway was inserted in first attempt ${ }^{5}$ ( $p$ value $0.64)$. There was no significant difference between the two groups (Table 3). Mild gagging ${ }^{6}$ occurred in 2 patients in Group I and 1 patient in Group II (Table 2) which is statistically not significant ( $\mathrm{p}$ value 0.05 ).

The mean duration of apnoea in Group I was $154.4 \pm$ $10.98 \mathrm{sec}$. and in Group II $208.44 \pm 20.10 \mathrm{sec}$ (p value 0.001 ). (Table 4). Statistical analysis showed a significant difference in the duration of apnoea between two groups. Pulse rate, systolic blood pressure and diastolic blood pressure were recorded before premedication, 1 minute prior to induction, 30 seconds post-induction and 1 minute after LMA insertion. Statistical analysis showed that there is no significant difference in Pulse rate (Table 5), Systolic blood pressure (Table 6), Diastolic blood pressure (Table 7) between the study groups. But the changes occur in the groups during the study time, which is not relevant.

\begin{tabular}{|c|c|c|c|}
\hline $\begin{array}{c}\text { Patient } \\
\text { Characteristics }\end{array}$ & Group I & Group II & $P$ value \\
\hline Age in Years & $28.04 \pm 7.18$ & $29.64 \pm 7.15$ & 0.43 \\
\hline $\begin{array}{c}\text { Sex } \\
\text { (Male/Female) }\end{array}$ & $8 / 17$ & $7 / 18$ & 0.76 \\
\hline Weight & $51.52 \pm 8.16$ & $49.56 \pm 7.41$ & 0.38 \\
\hline
\end{tabular}

\begin{tabular}{|c|c|c|c|c|c|c|}
\hline & Grading & \multicolumn{2}{|c|}{ Group I } & \multicolumn{2}{|c|}{ Group II } & P value \\
\hline \multirow{5}{*}{$\begin{array}{c}\text { Fascicula- } \\
\text { tions }\end{array}$} & & No & $\%$ & No & $\%$ & \multirow{5}{*}{$\begin{array}{c}\mathrm{p} \text { value } \\
0.001 \\
\text { (Significant) }\end{array}$} \\
\hline & None & 0 & 0 & 0 & 0 & \\
\hline & Mild & 22 & 88 & 2 & 8 & \\
\hline & Moderate & 3 & 12 & 23 & 92 & \\
\hline & Severe & 0 & 0 & 0 & 0 & \\
\hline \multirow{3}{*}{$\begin{array}{c}\text { Jaw } \\
\text { Relaxation }\end{array}$} & Good & 23 & 92 & 24 & 96 & \multirow{3}{*}{\begin{tabular}{|c|}
$\mathrm{p}$ value \\
0.55 \\
(Non- \\
Significant)
\end{tabular}} \\
\hline & Incomplete & 2 & 8 & 1 & 4 & \\
\hline & Poor & 0 & 0 & 0 & 0 & \\
\hline \multirow{4}{*}{ Gagging } & Nil & 23 & 92 & 24 & 96 & \multirow{4}{*}{$\begin{array}{c}\mathrm{p} \text { value } \\
0.05 \\
\text { (Non- } \\
\text { Significant) }\end{array}$} \\
\hline & Mild & 2 & 8 & 1 & 4 & \\
\hline & Moderate & 0 & 0 & 0 & 0 & \\
\hline & Severe & 0 & 0 & 0 & 0 & \\
\hline \multirow{4}{*}{ Coughing } & Nil & 25 & 0 & 25 & 0 & \\
\hline & Mild & 0 & 0 & 0 & 0 & \\
\hline & Moderate & 0 & 0 & 0 & 0 & \\
\hline & Severe & 0 & 0 & 0 & 0 & \\
\hline \multirow{4}{*}{$\begin{array}{c}\text { Laryngo- } \\
\text { spasm }\end{array}$} & Nil & 25 & 0 & 25 & 0 & \\
\hline & Mild & 0 & 0 & 0 & 0 & \\
\hline & Moderate & 0 & 0 & 0 & 0 & \\
\hline & Severe & 0 & 0 & 0 & 0 & \\
\hline
\end{tabular}

\begin{tabular}{|c|c|c|c|}
\hline $\begin{array}{c}\text { Number of } \\
\text { Attempts }\end{array}$ & Group I & Group II & Total \\
\hline First Attempt & 22 & 23 & 45 \\
\hline $\begin{array}{c}\text { Second } \\
\text { Attempt }\end{array}$ & 3 & 2 & 5 \\
\hline Total & $\mathbf{2 5}$ & $\mathbf{2 5}$ & $\mathbf{5 0}$ \\
\hline
\end{tabular}

Table 3. Number of attempts for successful LMA insertion

\begin{tabular}{|c|c|c|}
\hline Sl. No. & $\begin{array}{l}\text { Duration of APNOEA } \\
\text { in Seconds - Group I }\end{array}$ & $\begin{array}{l}\text { Duration of APNOEA } \\
\text { in Seconds - Group II }\end{array}$ \\
\hline 1 & 160 & 196 \\
\hline 2 & 166 & 224 \\
\hline 3 & 150 & 190 \\
\hline 4 & 140 & 210 \\
\hline 5 & 180 & 190 \\
\hline 6 & 146 & 240 \\
\hline 7 & 154 & 219 \\
\hline 8 & 138 & 190 \\
\hline 9 & 145 & 194 \\
\hline 10 & 153 & 220 \\
\hline 11 & 146 & 210 \\
\hline 12 & 153 & 198 \\
\hline 13 & 160 & 220 \\
\hline 14 & 140 & 240 \\
\hline 15 & 160 & 200 \\
\hline 16 & 176 & 260 \\
\hline 17 & 164 & 188 \\
\hline 18 & 150 & 206 \\
\hline 19 & 146 & 222 \\
\hline 20 & 160 & 182 \\
\hline 21 & 144 & 234 \\
\hline 22 & 170 & 186 \\
\hline 23 & 156 & 198 \\
\hline 24 & 148 & 200 \\
\hline 25 & 155 & 194 \\
\hline
\end{tabular}

Table 4. Time for Spontaneous resumption of respiration

The mean duration of apnoea in Group I was $154.4 \pm 10.98$ and in Group II was 208.44 \pm 10.10 .

\begin{tabular}{|c|c|c|c|c|c|}
\hline Source & $\begin{array}{c}\text { Sum of } \\
\text { Square }\end{array}$ & $\mathbf{d F}$ & $\begin{array}{c}\text { Mean } \\
\text { Square }\end{array}$ & $\mathbf{F}$ & Significance \\
\hline Groups & 81.92 & 1 & 81.92 & 0.36 & 0.55 (N.S) \\
\hline Time & 1214.62 & 3 & 404.87 & 19.04 & 0.001 \\
\hline \multicolumn{6}{c|}{ Table 5. Repeated measures, } \\
Analysis of Variance in Pulse Rate
\end{tabular}

\begin{tabular}{|c|c|c|c|c|c|}
\hline Source & $\begin{array}{c}\text { Sum of } \\
\text { Square }\end{array}$ & $\mathbf{d F}$ & $\begin{array}{c}\text { Mean } \\
\text { Square }\end{array}$ & F & Significance \\
\hline Groups & 2.0 & 1 & 2 & 0.08 & 0.93 (N.S) \\
\hline Time & 1246.24 & 3 & 415.41 & 19.55 & 0.001 \\
\hline \multicolumn{6}{|c|}{ Table 6. Systolic Blood Pressure } \\
\hline
\end{tabular}

\begin{tabular}{|c|c|c|c|c|c|}
\hline Source & $\begin{array}{c}\text { Sum of } \\
\text { Square }\end{array}$ & $\mathbf{d F}$ & $\begin{array}{c}\text { Mean } \\
\text { Square }\end{array}$ & $\mathbf{F}$ & Significance \\
\hline Groups & 30.42 & 1 & 30.42 & 0.19 & 0.67 (N.S) \\
\hline Time & 128.70 & 3 & 42.9 & 6.21 & 0.001 \\
\hline \multicolumn{7}{|c|}{ Table 7. Diastolic Blood Pressure } \\
\hline
\end{tabular}



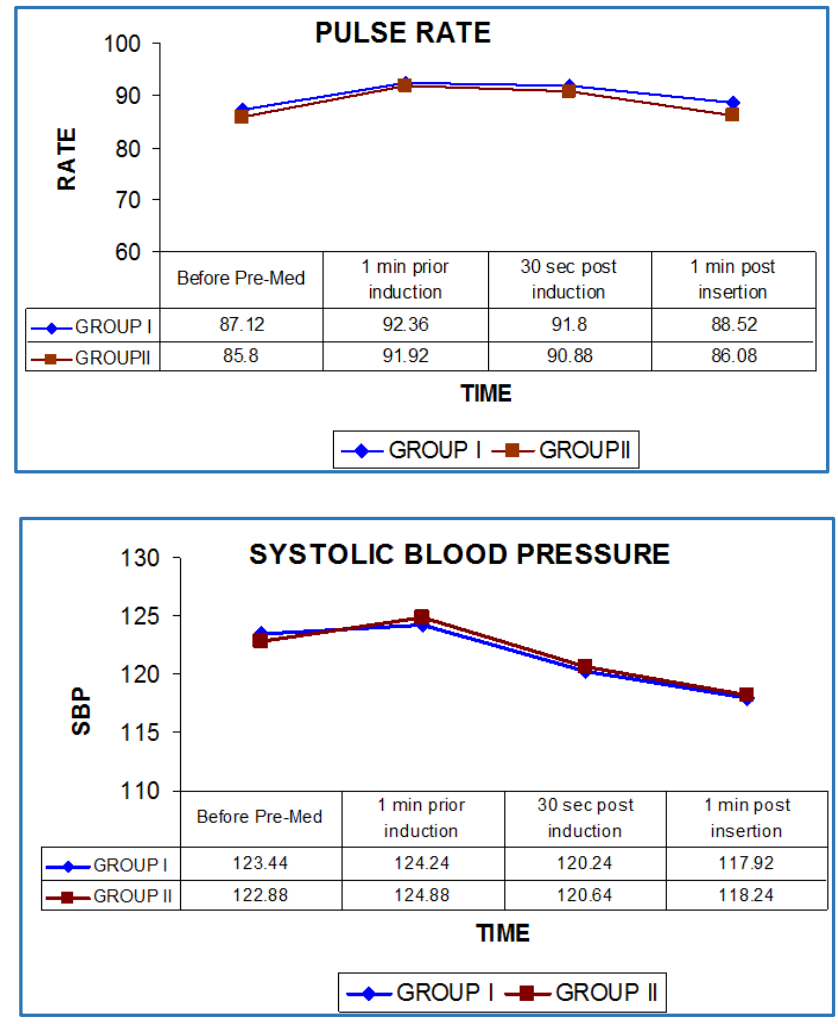

\section{DISCUSSION}

Adverse responses to insertion of laryngeal mask airway such as gagging and coughing may make correct positioning of laryngeal mask airway impossible. So laryngeal mask airway insertion requires suppression of upper airway reflexes adequately. Thiopentone has been assessed for its effectiveness in aiding laryngeal mask airway but produces less satisfactory conditions than propofol. But there may be problems related to use of propofol including the allergic potential of the drug.

Stonheim MD, Bree SE, Sneyd Jr. reported that easy insertion of laryngeal mask airway was seen in only $62 \%$ of patients with propofol anaesthesia, which means that the sole use of propofol does not always guarantee the successful insertion of LMA. Christine JC, Sitaram Raman, Timothy7 studied the effects of low dose succinylcholine for insertion of laryngeal mask airway following etomidate anaesthesia. They concluded etomidate and succinylcholine $0.25 \mathrm{mg} / \mathrm{Kg}$ is effective alternate for propofol for LMA insertion. PT Chui and E.W.W Chearm ${ }^{8}$ studied the use of low-dose mivacurium to facilitate easy insertion of laryngeal mask airway following propofol induction. There are studies using rocuronium ${ }^{7}$ along with propofol for LMA insertion. Koh KF, Cheng, FG $^{9}$ et al reported a combination of fentanyl, thiopentone with low doses of atracurium provided the conditions comparable with those of propofol for insertion of LMA. Chear EW, Chui PT10 studied the comparison of fentanyl, mivacurium and placebo for LMA insertion. MC Kewaring K, Bali IM Dundee JW reported, unpremedicated patients scheduled for elective surgery were allocated randomly to receive an unsupplemented induction dose of thiopentone or propofol. Visualisation of the vocal cords by standard laryngoscopy was possible more often after propofol.11 And also various studies compared the efficacy of propofol and thiopentone for LMA insertion.12,13,14 In our study, the addition of low doses of succinylcholine provides adequate suppression of airway reflexes, and better jaw relaxation for easy insertion of LMA.

\section{Summary}

The jaw relaxation was good in both the groups. There was no significant difference between the groups. The degree of fasciculations were more in Group II compared to Group I. There was no significant difference in gagging in both the groups. There was no coughing and laryngospasm in both the study groups. There was no significant difference in pulse rate, systolic blood pressure, diastolic blood pressure in both the groups. Patients were haemodynamically stable. ${ }^{15}$ Time for resumption of spontaneous respiration was significantly reduced in Group I compared to Group II. Both the groups had superior conditions when compared to thiopentone with local anaesthetics for LMA insertion. 16,17,18,19

\section{CONCLUSION}

We have demonstrated that following Thiopentone induction, administration of $0.5 \mathrm{mg} / \mathrm{Kg}$ succinylcholine IV produces optimal conditions for laryngeal mask airway insertion which is as good as administration of $1.0 \mathrm{mg} / \mathrm{Kg}$ of succinylcholine with apnoea time significantly shorter.

\section{ACKNOWLEDGEMENTS}

We are very grateful to the professors and assistant professors of the Department of General Surgery.

We are extremely thankful to the assistant professors and the postgraduates of the Department of Anaesthesiology for their help in carrying out this study.

We are thankful to the institutional ethical committee for their guidance and approval for this study. Last but not the least we thank all our patients for willingly submitting themselves for this study.

\section{REFERENCES}

[1] Brown GWL, Patel N, Ellis FR. Comparison of propofol and thiopentone for laryngeal mask airway insertion. Anaesthesia 1991;46(9):771-2.

[2] Stonheim MD, Bree SE, Sneyd JR. Facilitation of laryngeal mask airway insertion. Effects of lignocaine given intravenously before induction with propofol. Anaesthesia 1995;50(5):464-6.

[3] Naguib M, Samarkandi AH. The use of low dose rocuronium to facilitate laryngeal mask airway insertion. Middle East Journal of Anaesthesia 2001;16(1):41-54.

[4] Yoshino A, Hashimoto Y, Hiroshima J, et al. Low doses succinylcholine facilitates laryngeal mask airway insertion during thiopental anaesthesia. British journal of anaesthesia 1999;83(2):279-83.

[5] Ho KM, Chui PT. The use of mini-dose of suxamethonium to facilitate the insertion of a laryngeal mask airway. Anaesthesia 1999;54(7):686-9.

[6] Scanlon P, Carey M, Power M, et al. Patient response to laryngeal mask airway insertion after induction of anaesthesia with propofol or thiopentone. Canadian journal of Anaesthesia 1993;40(9):816-8.

[7] Christine JC, Raman S, Timothy. Use of low dose suxamethonium to facilitate laryngeal mask airway insertion under etomidate anaesthesia. Internet journal of anaesthesia 2003;6(2):80. 
[8] Chui PT, Chearm EW. The use of low dose mivacurium to facilitate insertion of laryngeal mask airway. Anaesthesia 1998;53(5):491-5.

[9] Koh KF, Chen FG, Cheong KF, et al. Laryngeal mask airway insertion using thiopental and low dose atracurium: a comparison with propofol. Canadian journal of Anaesthesia 1999;46(7):670-4.

[10] Cheam EW, Chui PT. Randomized double-blinded comparison of fentanyl, mivacurium or placebo to facilitate laryngeal mask airway insertion. Anaesthesia 2000;55(4):323-6.

[11] McKeating K, Bali IM, Dundee JW. The effects of thiopentone and propofol on upper airway integrity. Anaesthesia 1988;43(8):638-40.

[12] Grounds RM, Moore M, Morgan M. The relative potencies of thiopentone and propofol. European journal of anaesthesiology 1986;3:11-7.

[13] Driver I, Wilson C, Wilishire S, et al. Co-induction and laryngeal mask insertion a comparison of thiopentone versus propofol. Anesthesia 1997;52(7):698-700.
[14] Seavell CR, Cook TM, Cox CM. Topical lignocaine and thiopentone for insertion of a laryngeal mask airway; a comparison with propofol. Anaesthesia 1996;51(7):699-701.

[15] Hickeys S, Cameron AE, Asbury AJ. Cardiovascular response to insertion of brain's laryngeal mask Anaesthesia 1990;45(8):629-33.

[16] Brown GW, Ellis FR. Comparison of propofol and increased dose of thiopentone for laryngeal mask insertion. Acta anaesthesiologica scand 1995;39(8):1103-4.

[17] Bapat P, Joshi RN, Young E, et al. Comparison of propofol versus thiopentone with midazolam or lidocaine to facilitate laryngeal mask insertion. Canadian journal of anaesthesia 1996;43(6):564-8.

[18] Fahy LT, Mourik VA. A comparison of induction characteristic of thiopentone and propofol. Anaesthesia 1985;40:939-44.

[19] Cook TM, Seavell CR, Cox CM. Lignocaine to aid laryngeal mask airway with thiopentone. A comparison between topical and intravenous administration. Anaesthesia 1996;51(8):787-90. 